\title{
閉鎖性海域での海陸風と加つ低aの応答関係 \\ RESPONSE OF CHLOROPHYLL-a TO SEA-LAND BREEZE IN A SEMIENCLOSED SEA
}

\author{
長尾正之 1 ・朱小華 ${ }^{2}$ ・橋本英資 ${ }^{3}$. 吉田みゆき 4 高杉由夫 5 \\ Masayuki NAGAO, Xiaohua ZHU, Eisuke HASHIMOTO, \\ Miyuki YOSHIDA and Yoshio TAKASUGI \\ 1正会員 博（工） 工業技術院 中国工業技術研究所（干737-0197 吳市広末広2-2-2） \\ 2 工博 科学技術特別研究員 (下737-0197 吳市広末広 2-2-2) \\ 3 正会員 工業技術院 中国工業技術研究所 (下737-0197 呉市広末広2-2-2) \\ 4 広島大学 大学院 生物圈科学研究科 (下739-8528 東広島市鏡山1-4-4) \\ 5 農博 工業技術院 中国工業技術研究所（テ737-0197 吳市広末広2-2-2）
}

To investigate remediation and enhancement of polluted marine environment, an environmental monitoring have been carried out at a special floating laboratory in Kaita Bay. This monitoring includes meteorological observation, current profiling and water quality measurement. The results indicated that sea-land breeze, which is common phenomenon around the coast of the Seto Inland Sea, greatly affects the marine environment of Kaita bay. Especially, time variation of chlorophyll-a at $4 \mathrm{~m}$ depth had apparent diurnal oscillation that had good correlation with the movement of thermal stratification, which might be driven by sea-land breeze. The correlation between this oscillation and existence of sealand breeze had a statistical significance.

Key Words : Semienclosed sea, chlorophyll-a, sea-land breeze, remediation

\section{1. はじめに1)}

閒鎤性海域の代表とされる瀬戸内海では, 高度成長期 に行われた開発により, 2万haの沿岸浅海域が埋め立て られ，自然海岸線の割合が実に38\%にまで隇少した2)。こ の結果, 干潟や藻場が減少し, 内湾が持つ自然浄化機能 が大幅に低下した. また, 陸域や過剩な水産養殖から発 生する大量の栄養塩により, 特に海水交換が生じにくい 湾奥部では, 赤潮や貧酸素水塊の発生, ヘドロの堆積等 の問題が頻発している.このような状況に陥った沿岸海 域の環境を修復する技術の開発が，今，急務となってい る).

筆者らが所属する中国工業技術研究所（以下，中工研 と記す）では, 平成10年度から4ヶ年計画で「閉鎖性海 域の環境修復 ・ 創造技術の開発之効果検証に関する研 究」を開始し, 物理的・生物的な環境修復技術の開発を 行っている.これらの技術を実海域に適用するためには, 予め対象となる海域の気象, 海象, 水質, 河川流入等の 特性を十分に把握しておく必要がある. このため, 中工 研では平成11年より, 内湾の環境変動を連続して計測で きる浮体実験室（以下，マリンラボと記す）を広島湾の
枝湾である海田湾に設置した.

本稿では, このマリンラボの概要と, これまで得られ たデータをまず紹介する. そして, 海陸風がこの湾の流 動, 成首構造, および水質の変化に強い影響を及ぼして いることを示した上で, 海陸風とクロロフィルaの増減 の関係について論じる.

\section{2. 海田㴒とマリンラボの概要 ${ }^{11}$}

\section{（1）海田湾の概要}

マリンラボを設置する海域は, 次の三つの条件を満足 する必要があった. (1)海域環境の悪化が進んでおり, 実 際にその改善が強く望まれていること. (2)設置許可が比 較的容易に得られること. また, 漁業権が設定されてい ないこと. (3)中工研から近距離に位置し, 管理が容易で あること. 以上の条件を勘案した結果, マリンラボは広 島湾の枝湾の一つである海田湾に設置された. 図-1に広 島湾および海田湾の場所を示す.

海田湾は, 長さ $3.5 \mathrm{~km}$, 幅0.8kmの小湾である. 湾の水 表面積は2. $8 \mathrm{~km}^{2}$, 平均水深は $8 \mathrm{~m}$, 容積は 2200 万的である. 周囲は企業や公共施設で占有されているため, 全て人工 
構造物で囲まれており自然海岸線や干潟などは存在しな い. また，広島湾の最も奥にあるため，極度に閉鎖性が 強く，海水交換が行われにくい，特に海底環境の悪化が 著しく, 污染に強い多毛類以外に, 海底に生物はほとん ど住んでいない4).
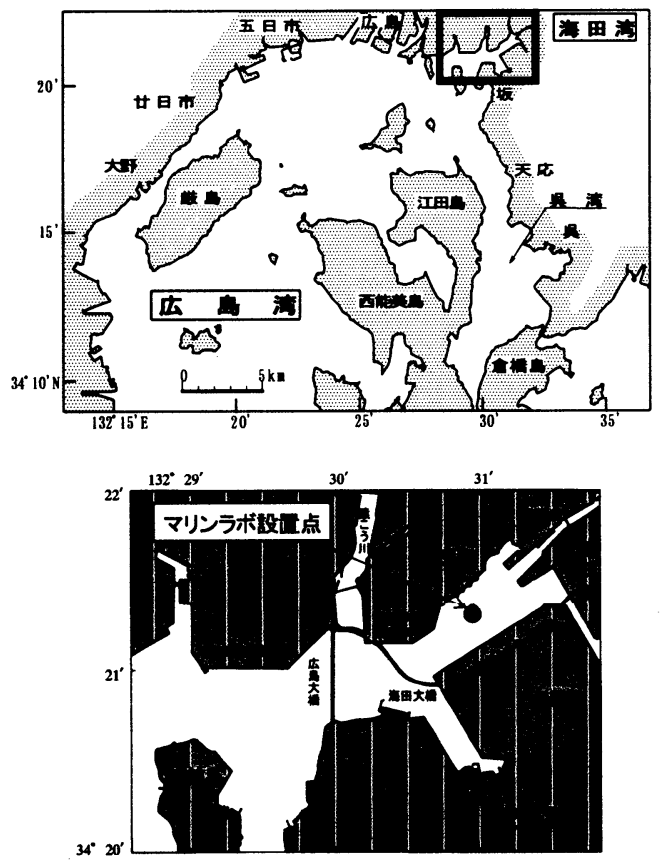

\section{図-1マリンラボの設置位置}

海田湾は，また，河川の影響を受けやすい湾でもある この湾の湾口北側には猿猴川が，また湾奥には瀬野川が 流入している. この他にも矢野川, 宮下川, 的場川の3 河川が海田湾に流入している. しかし，流域面積や流量 から考えて, 特に重要と考えられるのは, 瀬野川と猿猴 川の2河川である.

瀬野川は二級河川であり, 平水時の流量は約 $1 \mathrm{~m}^{3} / \mathrm{s}$ で ある. 一方，猿猴川は太田川の一支流である．猿猴川の 水位流量観測は行われていないので, 平水時の流量を次 のようにして求めた. 昭和63年から平成 9 年の流量基準 点の平水時流量は $51.31 \mathrm{~m}^{3} / \mathrm{s}$ である ${ }^{5)}$. また, 昭和 50 年に 建設省で策定された計画高水流量配分 ${ }^{5)}$ によると，流量 基準点では $7500 \mathrm{~m}^{3} / \mathrm{s}$, 猿猴川では $250 \mathrm{~m}^{3} / \mathrm{s}$ であり, その比 は3.3\%である. この比を先ほどの太田川平水時流量に乗 ずると，猿猴川の平水時流量は $1.7 \mathrm{~m}^{3} / \mathrm{s}$ となる.

ここで, 仮に猿猴川と瀬野川の平水時流量のみを利用 したとして, 海田湾の海水交換が年に何回行われるかを 検討する．海田湾の容積を 2200 万的とし，2河川の平水 時淡水流量の合計を $2.7 \mathrm{~m}^{3} / \mathrm{s}$ と考える. すると, 湾内水 を河川流量で入れ替えるのに要する時間は，約100日と なる. つまり，海水交換は 1 年間に3.5回は行うことが 可能である. なお, 通年で考えれば洪水が発生するため, 年平均流量は平水時流量よりも高くなる. したがって, たとえば1999年のように, 例年に比べて降水量が多い年
では, 交換回数も増えると予想される.

この他, 海田湾が位置する瀬戸内海沿岸地域は, 周囲 を山にとり囲まれているため，一般的に風が弱められる せいもあって, 昔から海陸風がよく発達する地域として も知られている6). しかし，これまで海陸風に対する関 心は，大気中に放出される污染物質の移流と拡散の担い 手という点に集中していた ${ }^{6)}$ 。一方, 湯浅 ${ }^{7}$ は，干潮河 川の流速鉛直分布が，夜間と昼間で大幅に異なることを 示し, この原因が海陸風に起因する点を明らかにした. また, 海域に入り込んだ栄養塩の挙動が夏季の昼間と夜 間では異なることを, 河口部での浮標追跡実験の結果か ら述べている. したがって，二つの主要流入河川を有し， また海陸風の強い影響下にある海田湾においても, 流 動・成層の変化や水質の物理的・生物的・化学的な物質 循環が, 海陸風の強い影響下にあると想像できる.

\section{(2) マリンラボの概要(1),8),9)}

マリンラボは1999年2月10日に海田湾に設置され，2月 12日から表-1に示した項目について自動観測装置による 計測を開始した. マリンラボの大きさおよび形状を図-2 に示す. マリンラボは, 内部にウエット・ラボとドラ イ・ラボの二つの実験室を有している. ウエット・ラボ は, 床下に $1.2 \mathrm{~m} \times 1 \mathrm{~m}$ の観測孔を持ち, ここから測定装置 を水中に吊り下げることができる. 一方, ドライ・ラボ には, 気象計の記録部，電源供給部および保守作業のた めの空間等が設けられている. この他，水面から高さ6m の位置の屋上には, 気象観測計が設置されている.

次に, マリンラボを使った観測結果の一例を示す. 瀬 戸内海は大潮時の干满差が3mを超えるため, 潮流の影響 を予め見積もっておくことが必要である. そこで, 1999 年3月26日から一ヶ月の間，ADCPによる潮流観測を実施 し，得られた流速データの調和解析を行った. 図-3-(a), (b)は, $M_{2}$ 潮流およひ残差流の鈶直プロファイルを示し ている. 図-3-(a)によれば, $M_{2}$ 潮流の振幅は，海面下 $1.5 \mathrm{~m}$ から $5 \mathrm{~m}$ まで2 2. $5 \mathrm{~cm} / \mathrm{s}$ で, ほぼ一定である. また,

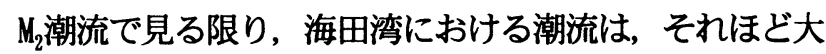
きな值とは言えない，一方，流向は方位角で $20 〜 30^{\circ}$ で

\section{表-1＼cjkstart環境データの観測項目}

\begin{tabular}{|c|c|}
\hline 観測装置 · 項目 & 観測項目 \\
\hline 気象観測計 & $\begin{array}{l}\text { 水面から高さ } 6 \mathrm{~m} \text { 上方で風向, 風速, } \\
\text { 気压, 気温, 日射, 雨量を測定 }\end{array}$ \\
\hline 流速計 & $\begin{array}{l}\text { 流向・流速（ADCPにより水深1.5mから } \\
\text { 0.5m間隔で海底まで. ただし，7月16日 } \\
\text { 以降は海底から上向きに設置） } \\
\text { この他, 電磁流速計による測定を実施. }\end{array}$ \\
\hline 水質 & $\begin{array}{l}\text { 水温（水面から0.5m間隔で水深 } 8 \mathrm{~m} \text { まで） } \\
\text { 㙁分（水深 } 0.5,2,3,5 \mathrm{~m}) \\
\text { 淘度・クロロフィルa（水深 } 1 \mathrm{~m}, 4 \mathrm{~m} ） \\
\text { DO (海底から高さ } 1 \mathrm{~m})\end{array}$ \\
\hline
\end{tabular}




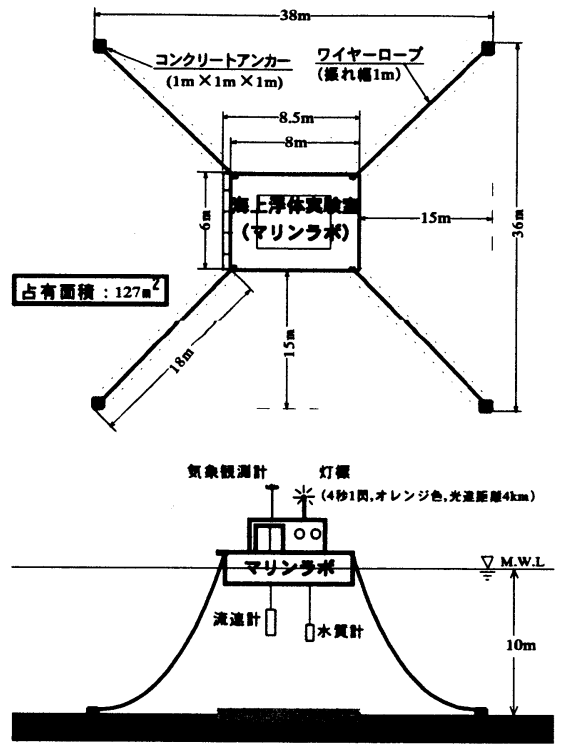

図-2 マリンラボの概要

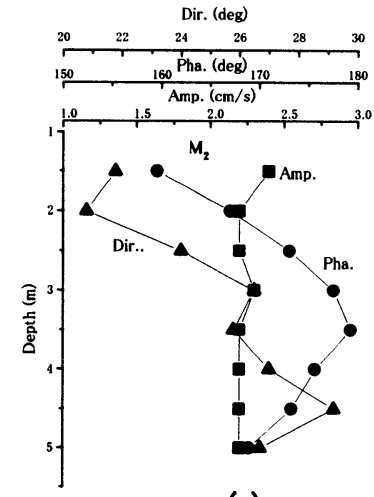

(a)

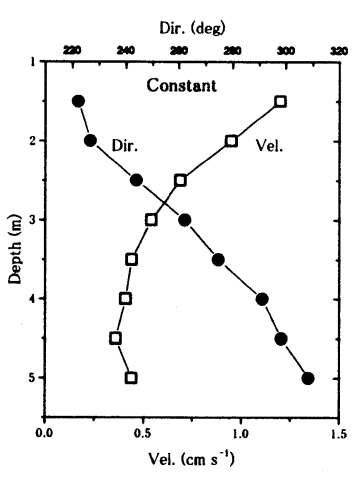

(b)
図-3 ADCPで得られた (a) $M_{2}$ 潮流成分と(b) 残差流成分

あり，ほぼ湾の長軸に沿った流れである. ただし, 表首 から底首に向かうにしたがって, やや東側にシフトして いる. 位相は全首で約 $20^{\circ}$ の違いが見られ，中層で遅れ が最大となっている.

次に図-3-(b) の残差流について見ると, 流速は水深 $1.5 \mathrm{~m}$ で最大值 $1.25 \mathrm{~cm} / \mathrm{s}$ を取り, 海底に向かって徐々に減 少する. 流向について見ると, 表首は $220^{\circ}$ で湾奥から 湾口に向かって流出しており, 海底ではこの值から時計 回りに約 $90^{\circ}$ 增加している. この残差流の鈶直分布は, 河川からの淡水流出を反映していると考えられる.

\section{3. 海陸風と流款・成庴の応答関係}

ここでは, 海陸風が発生した場合の, 流動・成首・水 質の典型的な変化を示す. 図-4は，8月1日か58月24日 までの気象観測の結果である. また, 図-5は, 瀬野川流 量 (広島県) を示す. 図-6は, 電磁流速計により測定さ
れた水面近傍の流速を示している. 図一7は, マリンラボ における水温変化を等温線で表現したものであり, 図-8 は, 同地点における塩分計の時間変化を表している. 図 -9は上層と中層のクロロフィルaの時間変化, 図-10は海 底から $1 \mathrm{~m}$ 上方で測定された潮位変化を示す。

この期間のうち8月5日〜8日は，雨はほとんど降らな かったものの, 最人で10巛// $\mathrm{s}$ 程度の北寄りの風が吹さ続 け, 水温鉛直分布は一様になっている. 強風が止んだ後, 速やかにほぼ元の水温分布に復帰していることから, 強 風による鈶直混合が進んだのではない，つまり，北風が 表層水を湾口側に押し出し，この体積を補う形で下首水 が表首に向かった結果, 見かけ上鈶直分布が一様化した ものと推察される. また8月17日〜18日にかけて広島で は総雨量81m的に達する大雨が降り ${ }^{10)}$, このため瀬野川流 量は 18 日深夜に最大で $30 \mathrm{~m}^{3} / \mathrm{s}$ に達した. ただし, $\mathrm{D}=3 \mathrm{~m} の$ 塩分計記録は $=0.5 \mathrm{~m} に$ 比べてほとんど変化せず, 水温も 均一になっていないため, 全水深の成層を一様化するほ ごの出水は生じなかった模様である.

さて, このような突発的な海域拱乱現象を除いて図-4 から図-9を概観する. まず風速・風向を見ると, 午後か らは $\mathrm{m} / \mathrm{s}$ の南奇りの風が吹き, 夜間は逆に北奇りの風に 変わる. 水面近傍の流速は, 潮流による半 ・日周変動に 加えて, この海陸風の切り替えにしたがった変化を示し ていると考えられる.

一方, クロロフィルaの変化（図-9）は, 表首と中首 で異なっている. 表層（D=1m）のクロロフィルaは, 強 風と洪水による海域擋乱時では前後の值に比べて下がる が, それ以外の時期では, 日周変動を伴った変化をして いることがわかる. 一方, 中首 $(\mathrm{D}=4 \mathrm{~m})$ は, 海域損乱時 を除けば，深夜に非常にはっきりとした最大值を取り， 反対に尽間の值は小さい. なお図-10の潮位に認められ る半日周変化は, 中層のクロロフィルaには認められな い.

中層のクロロフィルaがこのような変動をする原因が 植物プランクトンの日周鈶直移動ならば, 日の出ととも に表層へクロロフィルaが移動するため値は急減し, 逆 に日の入り時にはクロロフィルaの沈降により值は急増 するはずである. しかし，図-4の日射量と図-9-(b) とを 比べると, クロロフィルaの濃度変化は日射量と完全に は対応していない.

次に植物プランクトンがその場の流体運動（たとえば 密度流や内部波）を利用し, 生育環境が最適な位置に移 動した可能性が考えられる. たとえば図一7をよく見ると, $\mathrm{D}=4 \mathrm{~m}$ 付近を通る $23^{\circ} \mathrm{C}$ または $24^{\circ} \mathrm{C}$ 等温線が深夜0時頃に 鋭く下降していることがわかる. この原因として, 次の 機構が考えられる. 昼間に吹く海風は河川水を湾奥に押 し, 湾口部にある高塩分の表首水をマリンラボ近傍に運 ぶとともに, 表首水の厚みを増加させる1). この現象は 夜間に海風から陸風へと切り替わった後も, 中層ではし ばらく続くため, D=4mのクロロフィルa濃度にピークが 

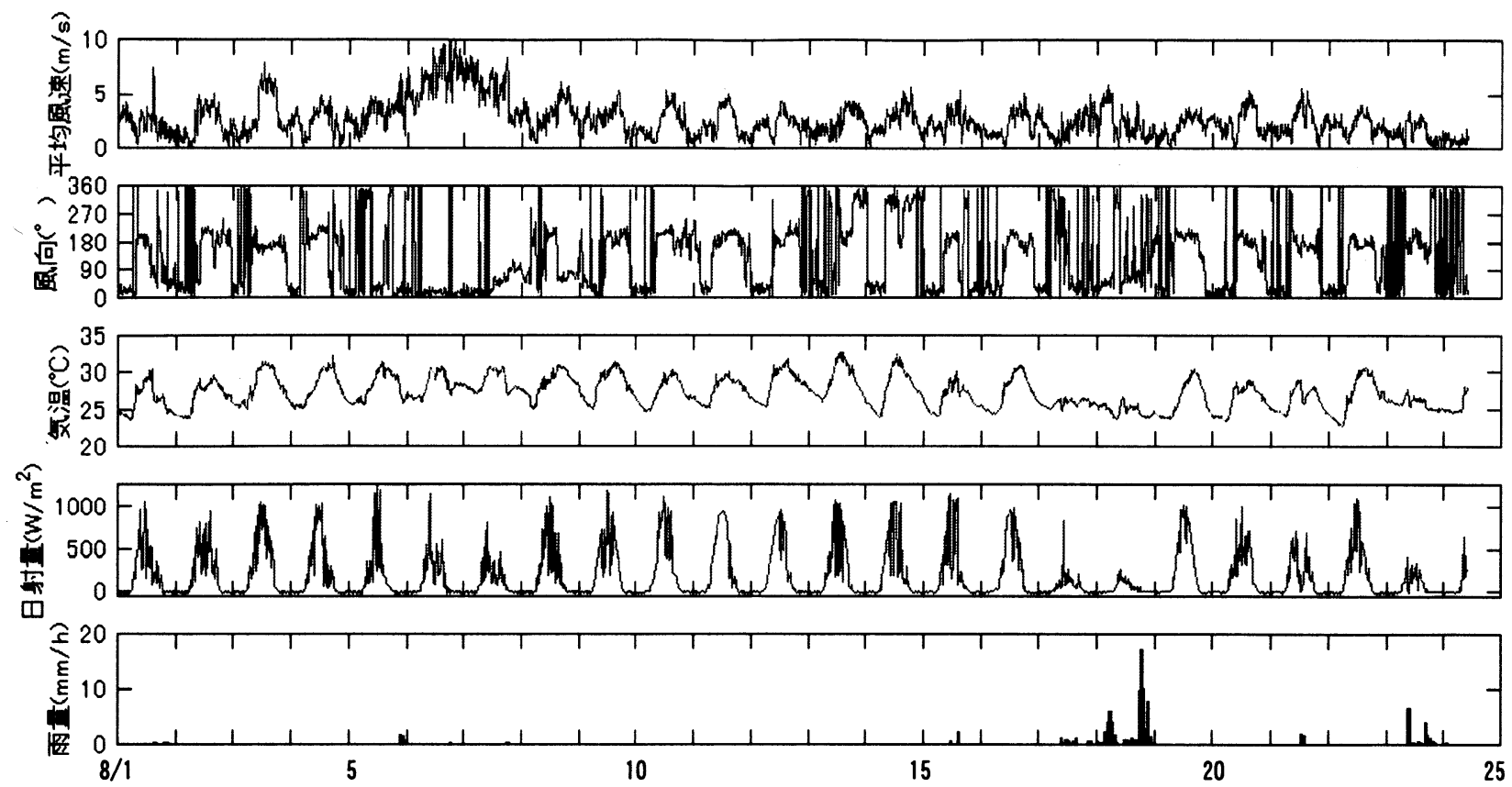

图-4 気象観測結果

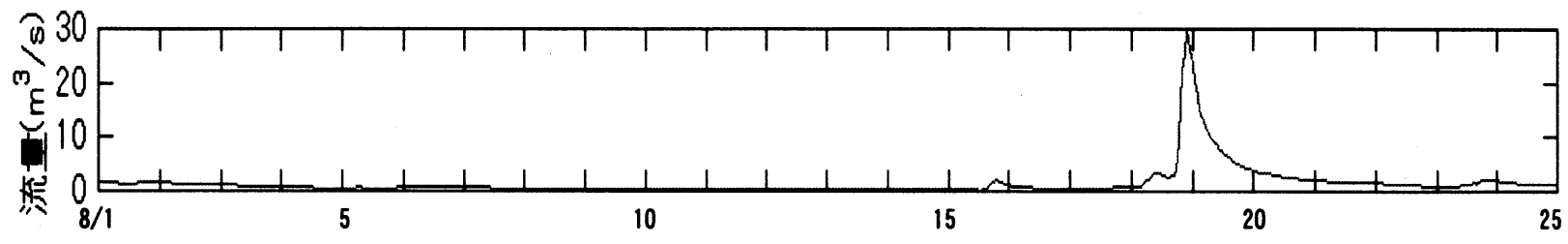

图-5 澒野川流量
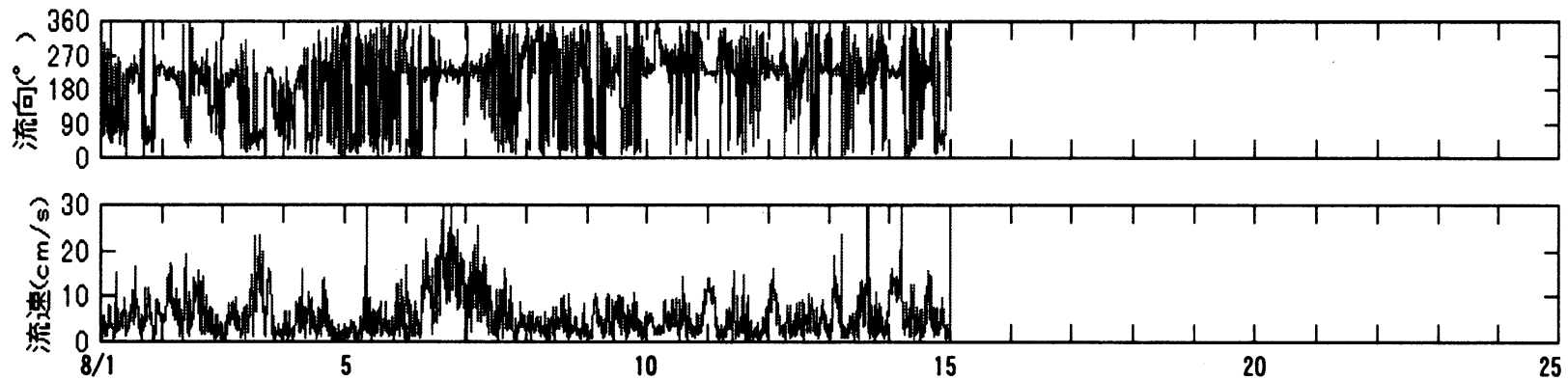

图-6 表層流速 $(D=0.5 \mathrm{~m}, 1999 / 8 / 1 \sim 15)$

生じるのは，深夜になると考えられる，一方，陸風が吹 き始めその大きさが強くなると，押し込められていた河 川水は湾口部へと流出する. この結果, 表層水の厚みは 薄くなり表首塩分は急減する. また, 中首には海底付近 の低水温・低クロロフィルの海水が現れる.

連続成層場に海陸風が吹き続けた場合の物理的な解析 をしていないので, この考えは推論に過ぎない.今後は 3次元流動モデル等を用いて, 詳しい検討を行いたいと 考えている.

\section{4. 海陸風の有無とクロロフィルaの対応}

海陸風が吹いた場合の, 流動, 成首, 水質の対応関係
を 3. で見た. ただし， $\mathrm{D}=4 \mathrm{~m}$ のクロロフィルaの変化を 海陸風と結びつけ，定量的な議論を行うためには，海陸 風が実際に吹いた日のデータを抜き出して議論しなくて はならない，一方で，図-4の風向・風速を見ても明らか なように，海陸風の基本的な過程とそれからのバリエー ションの区分を行うことは，それほど容易なことではな (あ). つまり, 何らかの基準を使って, 海陸風が吹いた かどうかを判断しなければならない，基準としては，風 の吹き方に着目した方法 ${ }^{111}, 12$ ， 気象条件で判断する方 法(13)，および両者を組み合わせて判断する方法(4), (15),16)が 提案されているが，ここでは海陸風の判断基準として, 吹き方のみに判断の基準を置いた宮田ら ${ }^{6}$ の基準を用い ることにする. ただし，元の基準では陸風の判定として 「陸寄りの風向 or 風速0.5m/s以下」を用いているが, 


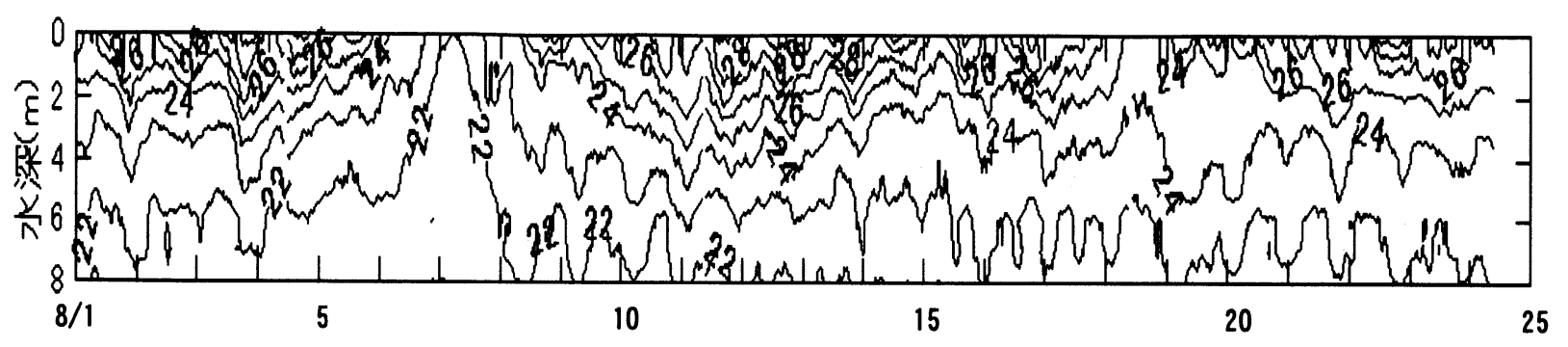

图-7 水温分布の経時変化

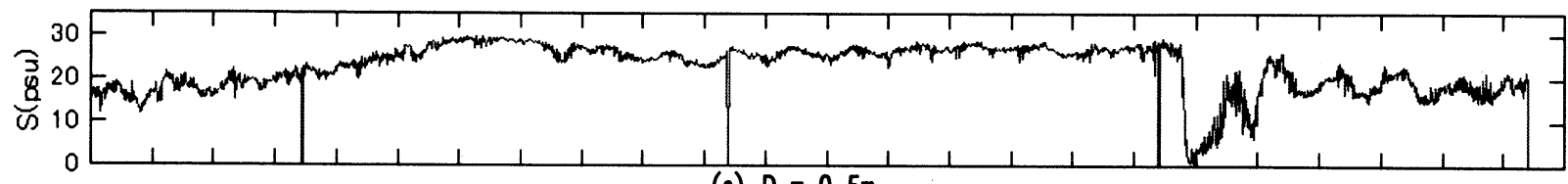

(a) $D=0.5 \mathrm{~m}$

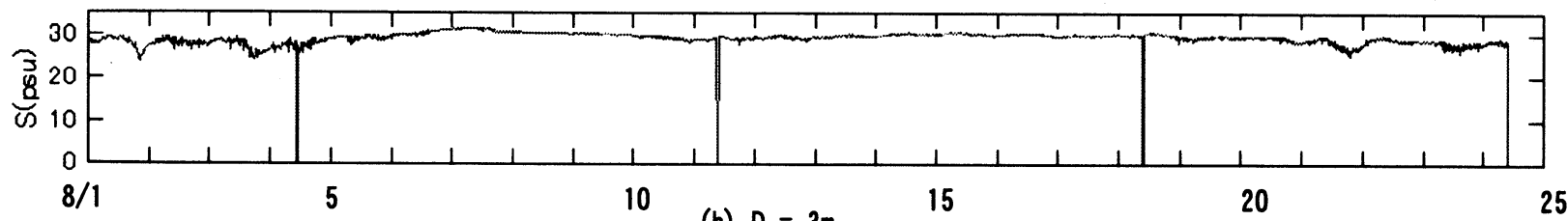

(b) $D=3 m$

図-8 塩分経時変化. (a) D=0.5m, (b) D= $3 \mathrm{~m} . \quad(8 / 4,11,18,24$ のスパイクは, 測器洗浄による.）

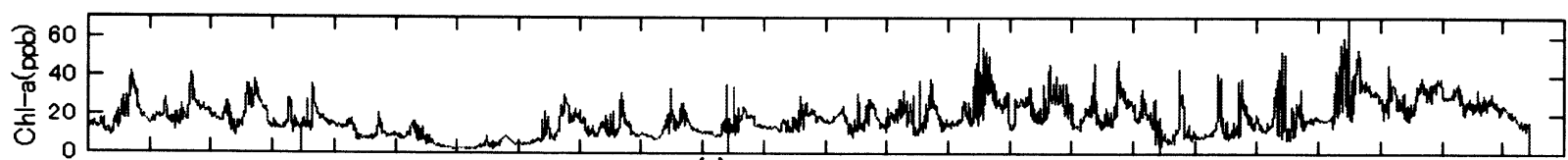

(a) $D=1 \mathrm{~m}$

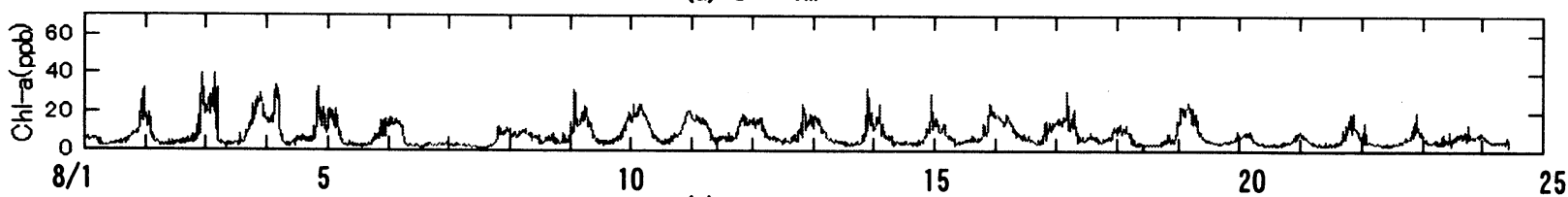

(b) $D=4 m$

图-9 吅化倘aの経時変化. (a) $D=1 m,(b) D=4 m$.

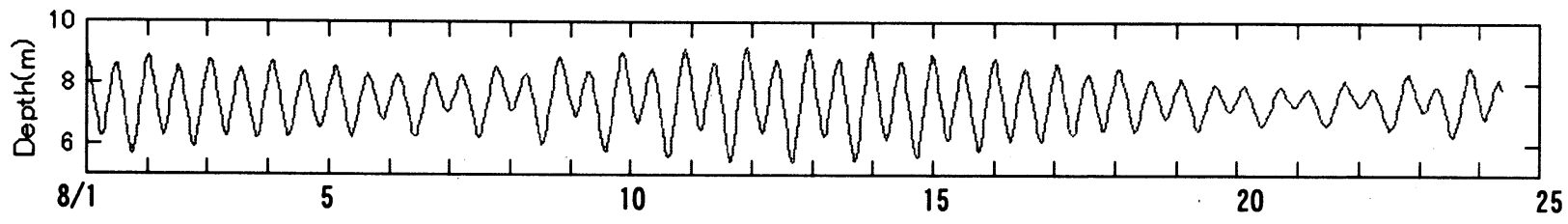

図-10 潮位記録（海底上1mで計測）

マリンラボは海トに設置されており，また瀬野川の川筋 にも当たるため, 風は終日吹いており, 夜間に風が弱ま る時間帯でも $0.5 \mathrm{~m} / \mathrm{s}$ 以上の風速はかなりの頻度で出現す る. そこで, 陸風の判定基淮のうち, 風速のしきい値を

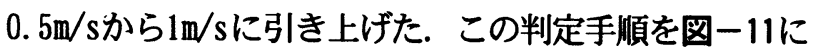
示す.

図-11の基準を使って，2月13日から8月23日までの海 陸風の有無を機械的に判断したところ, 全観測日192日 のうち, 海陸風が吹いていたと判定された日は110日で あり, 全体の57\%に相当していた. また, 月別の頻度は 表-2に示した通りであった.

次に, $\mathrm{D}=4 \mathrm{~m}$ のクロロフィルaについて, 海陸風由来と 思われるピークが，夜間に認められたかどうかを各観測 日ごとに判断する必要がある. クロロフィルaの平均值 は, 観測時期ごとに異なるため, ここでは(1)ピークが着

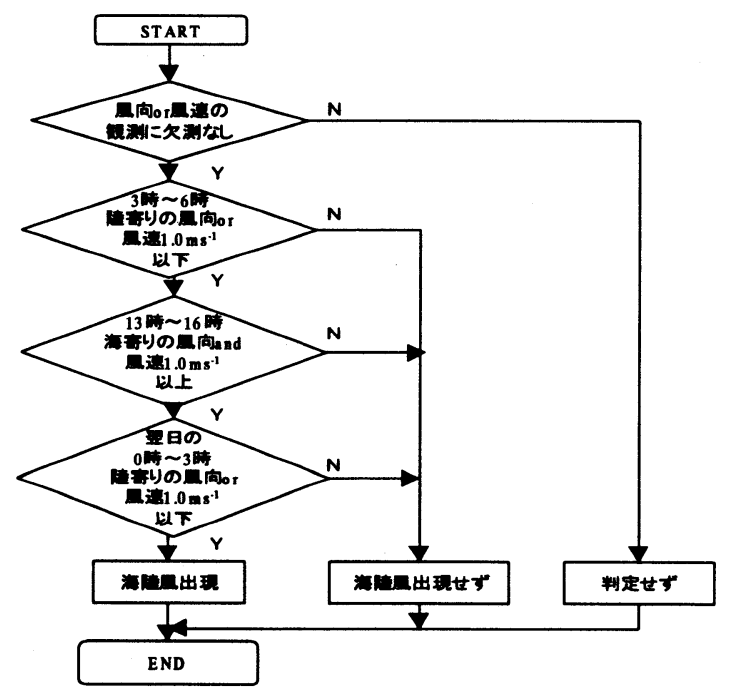

図-11 海陸風の判定手順（宮田ら ${ }^{6}$ ) の図2.2を修正） 
表-2 海陸風の有無と加了化a $(\mathrm{D}=4 \mathrm{~m})$ のピークとの対応

\begin{tabular}{|c|c|c|c|}
\hline 月 & $\begin{array}{c}\text { 海陸風 } \\
\text { 発生日数 }\end{array}$ & $\begin{array}{l}\text { クロロフ价 } \mathrm{a}(\mathrm{D}=4 \mathrm{~m}) に \\
\text { ピークが生したた日数 }\end{array}$ & $\begin{array}{l}\text { ピーク発生日の前日に } \\
\text { 海陸風が生したた数 } \\
\end{array}$ \\
\hline 2月(13-28日) & 10 & 16 & 9 \\
\hline 3月 & 13 & 6 & 4 \\
\hline 4月 & 16 & 3 & 1 \\
\hline 5月 & 22 & 17 & 12 \\
\hline 6月 & 16 & 10 & 7 \\
\hline 7月 & 17 & 10 & 7 \\
\hline 8月(1-23日) & 16 & 20 & 15 \\
\hline 合㝇 & 110 & 82 & 55 \\
\hline
\end{tabular}

目している日の0時前後の夜間に生じていること, (2) ピークが明膫であること，の二つの条件を基準に判断す ることにした. その結果, 全測定日192日のうち, D=4m のクロロフィルa濃度にピークが認められたのは82日で あり, 全体の $43 \%$ に相当していた.

さて, 注目している日に生じた $\mathrm{D}=4 \mathrm{~m}$ のクロロフィルa の上昇は，その前日に海陸風が吹いたことによって生じ ていると考えられる. 調べた結果, $\mathrm{D}=4 \mathrm{~m}$ のクロロフィル aにピークがあり, かつその前日に風データが揃ってい た81日のうち, 前日に海陸風が生じていた日は55日 （68\%）であった. 表-2は，以上の結果を月毎に整理し たものである. また, 海陸風の有無と $\mathrm{D}=4 \mathrm{~m}$ のクロロフィ ルaピークの有無を2x2分割表にまとめ, 有意水準5\%で検 定したところ, 関連性が認められた。

\section{5. おわりに}

広島湾の枝湾の一つである海田湾において, 流動, 成 層, 水質, 気象データの長期モニタリングを実施し, 環 境修復技術の実施に際しての基礎的データの取得と解析 を開始した. その結果, 以下の項目について知見を得た. 1) $\mathrm{M}_{2}$ 潮流成分を検討した結果, 潮流の大きさは2 $2.5 \mathrm{~cm} / \mathrm{s}$ であり, 極めて小さな値であった.

2) 8月観測時に認められた強風や洪水による海域擋乱現 象は, 湾の成層構造を一時的に変化させるものの, 全 水深にわたって海水を混合または交換するほどの効果 は持っていなかった.

3) 海陸風が平時の流動や成層, 水質の変動に強い影響を 与えている. 特にD=4mのクロロフィルaが深夜にピー クを持つのは, 海風により表層水の厚みが増すからだ

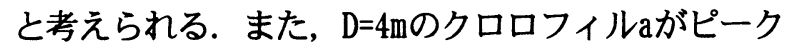
を持ったケースのうち, 前日に海陸風が生じていた割 合を調べたところ68\%であった. また, 海陸風の有無 とクロロフィルaのピークとの関連を $2 \times 2$ 分割表によっ て調べたところ, 有意水準5\%で関連性が認められた.

今後は, 3次元流動モデル等を利用して, 海陸風が吹 いた場合に, どのような機構で表層水の厚みが増し, ク ロロフィルa濃度が増加するのかという点について解析
を続けていきたいと考えている.

謝辞 : マリンラボの設置に際し, 広島県広島港港湾振興 局, 海上保安庁広島海上保安部ならびに海田湾周辺の関 係企業や漁業協同組合からの多大なご協力を頂いた．ま た建設省中国地方建設局太田川工事事務所からは，太田 川の水位・流量デー夕等を提供して頂き，広島県土木建 築部河川課からは, 瀬野川の水位流量データを提供して 頂いた. 以上，ここに記して謝意に代えさせていただく.

\section{参考文献}

1) 橋本英資, 朱小華, 長尾正之, 高杉由夫, 上嶋英機 : 海洋環 境修復に向けての新たな取り組み一海田湾におけるマリンラ ボ設置と長期モニタリングー, 中国工業技術研究所報告, No.53, pp.15-21, 1999.

2) 環境庁水質保全局 : 平成8年度瀬戸内海の環境保全一資料編 一, 瀬戸内海環境保全協会, p.161, 1997.

3) 上鴆英機: ミチゲーション, 治岸の環境圈（平野敏行監修）, フジ・テクノシステム, pp.933-943, 1597p., 1998.

4) 三島康史, 星加 章, 谷本照巳, 上嶋英機 : 海田湾における 環境修復技術の研究 (III) 一海田湾の生物・化学環境一, 1999年度日本海洋学会秋季大会講演要旨集, p.108, 1999.

5) 建設省中国地方建設局太田川工事事務所 : 太田川・小瀬川概 要 (平成11年度), 1999.

6) 宮田賢二編 : 広島県の海陸風, 渓水社, 395p., 1982.

7) 湯浅一郎 : 内海における循環流・フロントと栄養塩類の挙動 に関する研究，中国工業技術研究所報告，No.12, 184p., 1994.

8) 高杉由夫, 朱小華, 橋本英資, 星加章, 三島博史, 谷本照巳, 長尾正之 : 海田湾における環境修復技術の研究(I)ーマリンラ ボの概要一，1999年度日本海洋学会秋季大会講演要旨集, p.106, 1999.

9）朱小華, 橋本英資, 長尾正之, 高杉由夫 : 海田湾における 環境修復技術の研究(II)一マリンラポによる長期モニタリ ング計測の速報一，1999年度日本海洋学会秋季大会講演要 旨集, p.107, 1999.

10) 広島地方気象台編 : 広島県気象月表（平成11年8月）, 日本 気象協会中国センター, 1999.

11) 岸田和博 : 広島空港における風の特性一その 2 -海陸風, 昭和42年度中国区気象研究会誌，pp.2-1-2-10, 1968.

12) 吉門 洋 : 海陸風に対する気圧配置の影響, 公害, Vol.13, No.5, pp.36-45, 1978.

13）佐橋 謙: 岡山周辺の海陸風について, 天気, Vol.25, No.5, pp.357-363, 1978.

14) 北林興二 : 海陸風の統計的解析, 公害, Vol.11, No.5, pp.80-98, 1976.

15) 江口恒夫 : 大阪市の海陸風について一地上風データの統計 解析一, 天気, Vol.24, No.12, pp.739-746, 1977.

16) 森 征洋 : 香川・徳島における海陸風の統計的性質につい $\tau$, 日本気象学会関西支部例会講演要旨集, pp.14-17, 1979.

(1999. 9. 30受付) 